\title{
Effects of low dose of bisphenol A on the proliferation and mechanism of primary cultured prostate epithelial cells in rodents
}

\author{
DONGYAN HUANG ${ }^{1-3}$, JIANHUI WU ${ }^{2,3}, \mathrm{XIN} \mathrm{SU}^{2,3}, \mathrm{HAN} \mathrm{YAN}^{2,3}$ and ZUYUE SUN ${ }^{2,3}$ \\ ${ }^{1}$ School of Pharmacy, Fudan University, Shanghai 200433; ${ }^{2}$ National Evaluation Centre for The Toxicology \\ of Fertility Regulating Drugs; ${ }^{3}$ National Population and Family Planning Key Laboratory of Contraceptive \\ Drugs and Devices, Shanghai Institute of Planned Parenthood Research, Shanghai 200032, P.R. China
}

Received March 10, 2016; Accepted January 12, 2017

DOI: $10.3892 / \mathrm{ol} .2017 .6469$

\begin{abstract}
Bisphenol A (BPA) is a well-known endocrine disruptor compound(EDC) that aggravates testosterone-induced benign prostate hyperplasia by increasing the relative weight of the ventral and dorsolateral prostate in rats. This phenomenon is primarily attributed to the exogenous estrogen effect of BPA. However, the direct effect of BPA on prostate cells has not been characterized. The present study investigated the proliferative effect and possible mechanisms of action of BPA on the prostatic epithelium of rats. The ventral prostate epithelial cells were cultured in vitro and the proliferation effects of BPA on cells were studied. The cells were identified as prostatic epithelial cells, and cell viability, cell apoptosis and the expressions of androgen receptors (AR) and estrogen receptors (ER), were detected. It was observed that $0.01-1 \mathrm{nM}$ BPA promoted cell growth, with $1 \mathrm{nM}$ BPA inducing the greatest increase in the rate of cell growth. However, BPA-treated cells exhibited no marked morphological changes compared with the control group. The cell apoptosis rate in each BPA-treated group was lower compared with the control group. The expression levels of ER $\alpha$ and ER $\beta$ increased, but the expression of AR decreased. The present study demonstrated that environmental exposure to BPA directly promoted the proliferation of prostate cells in rats through increasing the expression of estrogen receptors, reducing the expression of androgen receptors of the cells and decreasing apoptosis-induced cell death.
\end{abstract}

\section{Introduction}

The growth and development of the prostate is regulated by hormones. Abnormal hormonal secretions lead to prostatic

Correspondence to: Dr Jianhui Wu, National Evaluation Centre for The Toxicology of Fertility Regulating Drugs, Shanghai Institute of Planned Parenthood Research, 2140 Xie Tu Road, Xuhui, Shanghai 200032, P.R. China

E-mail: wujh_731@163.com

Key words: bisphenol A, environmental estrogen, epithelial cell, in vitro, primary culture, prostate lesions, including benign prostatic hyperplasia (BPH). A previous study by Alonso-Magdalena et al (1) reported that $\mathrm{BPH}$ is not a disease of prostatic stromal proliferation, but of the accumulation of mesenchymal-like cells derived from the prostatic epithelium and endothelium. Therefore, the proliferation of epithelial cells in the hyperplastic acini is indispensable for benign growth of the prostate gland.

Bisphenol A (BPA), a xenoestrogen, is a key monomer and industrial plasticizer, fungicide, flame retardant and component of epoxy resins used in food packaging, including cans and metal jar lids $(2,3)$. In humans, data from previous studies suggests that BPA may induce adverse outcomes and medical conditions, particularly on the reproductive and metabolic systems. However, the majority of these studies examine non-occupationally exposed people, who may be considered 'low dose', and thus these studies support the hypothesis that average levels of BPA exposure is sufficient to cause toxicity and affect human health (4). 'Low dose' has become a widely used term referring to toxicity studies for BPA that has been considered more informative about the potential health risk in humans compared with higher exposure studies (5). There are numerous animal studies demonstrating causal associations between BPA exposure and harm.

As an endocrine disruptor, BPA stimulates cellular responses at low concentrations, below the levels where BPA is expected to bind to classical nuclear estrogen receptors (ERs). For example, BPA altered the differentiation pattern of periductal stromal cells of the ventral prostate by diminishing the expression of androgen receptors (AR) andprostatic acid phosphatase (PAP) (6). Additionally, studies have demonstrated that BPA induces PCa cell migration via the modulation of the ion channel protein expression involved in calcium entry and in cancer cell migration (7). In addition to the adverse effect in vitro, BPA is known to affect prostate weight in rats $(8,9)$ and elicit cytokeratin 10 expression in the prostatic epithelium of mice (10). The administration of $10 \mu \mathrm{g} / \mathrm{kg}$ BPA to Sprague-Dawley (SD) rats on days 1,3 and 5 markedly increased the incidence of adult estrogen-induced prostate intraepithelial neoplasia compared with control rats (11). We have previously demonstrated that environmental exposure to a low daily dose, $10 \mu \mathrm{g} / \mathrm{kg}$ intragastric, of BPA may induce proliferation of the ventral prostate in adult rats by increasing the estrogen to androgen ratio and upregulating the expression of prostaglandin D2 synthase to 
promote the production of dihydrotestosterone (12). However, a direct association between low dose BPA and alterations to the prostatic epithelium has not been investigated.

Based on the aforementioned evidence, it is hypothesized that environmental exposure to BPA may promote the proliferation of prostate cells in the ventral prostate. In the present study, the possible mechanisms of action and the direct proliferative influence of BPA on primary cultured prostatic epithelium in rats were examined.

\section{Materials and methods}

Ethical standards. All animals in the present study were treated humanely according to the Guide for the Care and Use of Laboratory Animals of the Shanghai Institute of Planned Parenthood Research Animal Care and Use Committee (Shanghai, China).

Animals and housing. Male SD rats aged 10 weeks and weighing $240 \mathrm{~g}$ were purchased from Sino-British SIPPR/BK Laboratory Animal Co., Ltd., Shanghai, China. The animals were housed on sawdust bedding in standard polypropylene cages. Drinking water and a pellet diet (Shanghai Shilin Science \& Tech Co., Ltd, China) were available ad libitum in glass bottles. The rooms were maintained at temperatures between 20 and $26^{\circ} \mathrm{C}$ and 40-70\% humidity under a 12:12 h light: dark cycle. Animals were anesthetized with pentobarbital sodium following 5 days of adaptive breeding. All animal procedures were approved by the Animal Care and Use Committee of Shanghai Institute of Planned Parenthood Research (Shanghai, China), and conformed to the Guide for the Care and Use of Laboratory Animals (13).

Reagents. BPA (lot no., 162k0715; purity, 95\%) and collagenase II were purchased from Sigma-Aldrich; Epidermal growth factor and cholera toxin were purchased from Merck KGaA (Darmstadt, Germany). Insulin and transferrin were purchased from R\&D Systems China Co., Ltd. (Shanghai, China). The RPMI-1640 medium (without phenol red, with glutamine) was from Gibco; Thermo Fisher Scientific, Inc. (Waltham, MA, USA). RPMI-1640 medium (with glutamine) was supplied by Hyclone; GE Healthcare Sciences (Logan, UT, USA). Fetal bovine serum (FBS) was sourced from Hangzhou Sijiqing Biological Engineering Materials Co., Ltd. (Hangzhou, China). Mouse anti-pan cytokeratin (cat. no. BM0034), rabbit anti-androgen receptor (cat. no. BA0004), rabbit anti-ER $\alpha$ (cat. no. BA0345), rabbit anti-ER $\beta$ (cat. no. BA2210), StreptAvidin Biotin peroxidase Complex (SABC; SA1022) kit, and 3'3 diaminobenzidine (DAB; cat. no. AR1022) kit were purchased from Wuhan Boster Biological Technology, Ltd. (Wuhan, China). Dimethyl sulphoxide (DMSO) was sourced from Shanghai Shisheng Cell Biology Technology Co., Ltd. (Shanghai, China). Cell Counting Kit-8 (CCK-8) was purchased from Dojindo Molecular Technologies (Kumamoto, Japan). Annexin V-fluorescein isothiocyante (FITC), propidium iodide (PI) and $5 \mathrm{X}$ binding buffer were purchased from Merck \& Co., Inc. (Whitehouse Station, NJ, USA).

Cell culture. As described previously (14), the ventral prostates were removed, weighed and cut into $1.0-\mathrm{mm}^{3}$ blocks.
Subsequent to the addition of $675 \mathrm{U} / \mathrm{ml}$ collagenase II, the tissue suspension was blown 3 times with a straw and incubated at $37^{\circ} \mathrm{C}$ for $1 \mathrm{~h}$. The suspension was then cooled to $4^{\circ} \mathrm{C}$ and looped through 200-, 300- and 400-mesh sieves to obtain individual cells. The cells were collected subsequent to centrifugation at $4^{\circ} \mathrm{C}$ at $1,500 \times \mathrm{g}$ for $5 \mathrm{~min}$, and dispersed in RPMI-1640 at a concentration of $5 \times 10^{5}$ cells $/ \mathrm{ml}$. The cells were seeded in RPMI-1640 culture medium supplemented with $10 \% \mathrm{FBS}, 100 \mu \mathrm{g} / \mathrm{ml}$ penicillin, $100 \mathrm{U} / \mathrm{ml}$ streptomycin, $10 \mu \mathrm{g} / 1$ epidermal growth factor, $10 \mu \mathrm{g} / 1$ cholera toxin, $5 \mathrm{mg} / 1$ transferrin and $5 \mathrm{mg} / \mathrm{l}$ insulin, and cultured at $37^{\circ} \mathrm{C}$ with $5 \%$ $\mathrm{CO}_{2}$, changing the culture medium every 3-5 days.

Cell identification. The cells were dispersed at a density of $1 \times 10^{5} / \mathrm{ml}$ and seeded in 12 -well plates for culturing. The medium was removed subsequent to 12 days of adherent growth. The slides were fixed with $10 \%$ formalin for $60 \mathrm{~min}$ and endogenous peroxidase was quenched with hydrogen peroxide in methanol solution (fresh, $30 \% \mathrm{H}_{2} \mathrm{O}_{2}$; methyl alcohol; dilution, 1:50) for $30 \mathrm{~min}$. The cells were washed with distilled water and immersed in $5 \%$ bovine serum albumin for $20 \mathrm{~min}$ at room temperature to block the non-specific binding sites prior to incubation with mouse anti-pan cytokeratin (dilution, 1:100) in a wet box at $4^{\circ} \mathrm{C}$ overnight. Biotin-labeled goat anti-rabbit IgG (contained within the SABC kit; ready-to-use) and SABC kit were added successively at $37^{\circ} \mathrm{C}$ for $20 \mathrm{~min}$, followed by staining with a DAB kit. The sections were counterstained with hematoxylin and dehydrated, washed, mounted and observed under a Motic inverted microscope.

Treatment. Theprostatic epithelium suspension was seeded in 96-well plates and 24-well plates, and each hole was filled with $200 \mu \mathrm{l}$ suspension. The culture medium was replaced every 3 days. Subsequent to 12 days cultivation, the culture medium was substituted with phenol red-free RPMI-1640 without serum, and BPA was added to make a final concentration of $0.01,0.1,1,10,100$ and $1000 \mathrm{nM}$. This solution was maintained for $72 \mathrm{~h}$, subsequently the cells were processed for subsequent experiments. DMSO was used as the control, and the final concentration of the solution was below $0.5 \%$.

Cell morphological analysis by Giemsa. The medium of prostatic epithelium inoculated in 24-well plates was discarded subsequent to treatment. The plates were then washed twice with physiological saline prior to fixation with $95 \%$ ethanol for $30 \mathrm{~min}$ and staining with Giemsa for $15 \mathrm{~min}$. The reactions were halted with water and the images were captured with a Motic inverted microscope.

Cell viability assay by $C C K-8$. The supernatant of prostatic epithelium inoculated in the 96-well plates was discarded, and the cell viability was detected by the WST-8 assay with CCK-8, according to the protocol of the manufacturer. Absorbance was measured at $450 \mathrm{~nm}$ using a microplate reader. The cell viability was calculated using the formula: Cell viability $(\%)=[$ (the experimental value-the blank value) / (the control value-the blank value)] x100. A cell viability chart was then drawn.

Detection of apoptosis by flow cytometry. Subsequent to producing the cell viability chart, the proliferation mechanism 
of BPA on prostate epithelial cells was investigated. The cells were treated with $0.01,0.1$ and $1 \mathrm{nM}$ BPA for $72 \mathrm{~h}$, respectively, and the prostatic epithelia were then digested to obtain single cells at a density of $1 \times 10^{6} / \mathrm{ml}$ and centrifuged at $4^{\circ} \mathrm{C}$ and $1,500 \mathrm{x} g$ for $5 \mathrm{~min}$. The supernatant was discarded and the cells were washed with the binding buffer, centrifuged $\left(4^{\circ} \mathrm{C}, 1,500 \mathrm{x} \mathrm{g}\right)$ and incubated with $100 \mu \mathrm{l}$ Annexin V-FITC for $10 \mathrm{~min}$ at room temperature. Washing and centrifugation $\left(4^{\circ} \mathrm{C}, 1,500 \times \mathrm{g}\right)$ were repeated, followed by the addition of PI. The mixture was incubated for $20 \mathrm{~min}$ at $4^{\circ} \mathrm{C}$, and cell apoptosis was detected by flow cytometry (FACSCalibur ${ }^{\mathrm{TM}}$, BD Biosciences, Franklin Lakes, NJ, USA).

Evaluation of AR and ER expression by immunocytochemistry analysis. The cells were dispersed at a density of $1 \times 10^{5} / \mathrm{ml}$ and seeded in 12-well plates for culturing. The medium was removed subsequent to 12 days of adherent growth. The slides were fixed with $10 \%$ formalin for 60 min and endogenous peroxidase was quenched with hydrogen peroxide in methanol solution (fresh, $30 \% \mathrm{H}_{2} \mathrm{O}_{2}$; methyl alcohol, dilution, 1:50) for $30 \mathrm{~min}$. The cells were washed with distilled water and immersed in $5 \%$ bovine serum albumin for $20 \mathrm{~min}$ at room temperature to block the non-specific binding sites prior to incubation with the anti-androgen receptor, anti-ER $\alpha$ and anti-ER $\beta$ primary antibodies (dilution, 1:100) in a wet box at $4^{\circ} \mathrm{C}$ overnight. Biotin-labeled Goat Anti-Rabbit IgG and SABC were added successively at $37^{\circ} \mathrm{C}$ for $20 \mathrm{~min}$, followed by staining with a DAB kit. The sections were counterstained with hematoxylin and dehydrated, washed, mounted, and observed under a Motic inverted microscope. Finally, 120 cells in each group were randomly selected to obtain the mean values with the Motic Images Advanced 3.2 software (Motic, Kowloon, Hong Kong).

Statistical analysis. Data were analyzed using SPSS version 11.0 (SPSS, Inc., Chicago, IL, USA) and expressed as the mean \pm standard deviation of three experimental repeats. Statistical comparisons were performed by one-factor analysis of variance. If statistically significant, the differences between control and treatment groups were tested by the least-squares means test. $\mathrm{P}<0.05$ was considered to indicate a statistically significant difference.

\section{Results}

Cell morphological analysis. Giemsa staining revealed that the cultured cells were flattened and polygonal, the nucleus was approximately oval and located in the center of the cytoplasm and the cells were closely linked and appeared to grow in clusters. All these features conformed to the features of epithelial cells (Fig. 1). Subsequent to treatment of the prostatic epithelium with 0.01-1,000 nM BPA for $72 \mathrm{~h}$, no marked changes in cell morphology were observed compared with the control group (Fig. 2).

Cell viability. The cells were exposed to 0.01-1,000 nM BPA, and cell viability was tested by the CCK-8 method. At doses of 0.01-1 nM BPA, the cells exhibited growth-promoting activity and the cell survival rate increased as BPA dose increased. In the cells exposed to a dose of BPA $>1 \mathrm{nM}$, there was less
Table I. Effects of BPA on the apoptosis of prostate epithelial cells.

\begin{tabular}{lccc}
\hline $\begin{array}{l}\text { Dose } \\
(\mathrm{nM})\end{array}$ & $\begin{array}{c}\text { Necrotic } \\
(\%)\end{array}$ & $\begin{array}{c}\text { Living } \\
\text { cells }(\%)\end{array}$ & $\begin{array}{c}\text { Apoptotic } \\
\text { cells }(\%)\end{array}$ \\
\hline Control & 3.15 & 89.64 & 4.87 \\
BPA (0.01) & 0.70 & $96.14^{\mathrm{a}}$ & $2.72^{\mathrm{a}}$ \\
BPA (0.1) & 1.86 & $94.09^{\mathrm{a}}$ & $2.53^{\mathrm{a}}$ \\
BPA (1) & 1.14 & $93.92^{\mathrm{a}}$ & $2.77^{\mathrm{a}}$ \\
\hline
\end{tabular}

${ }^{a} \mathrm{P}<0.01$ vs. control group.

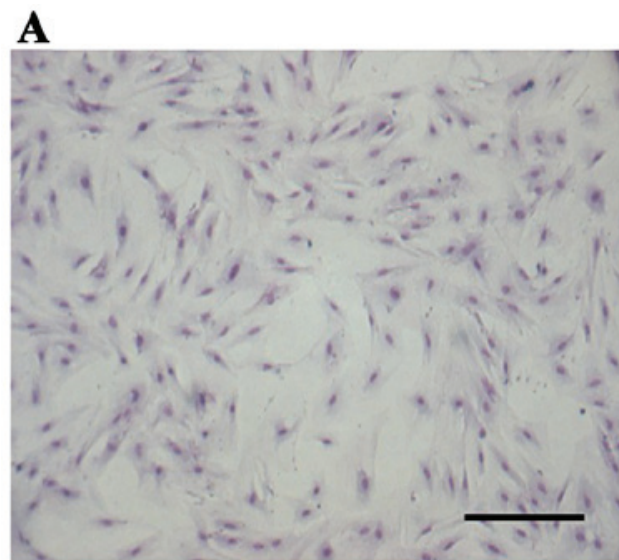

B

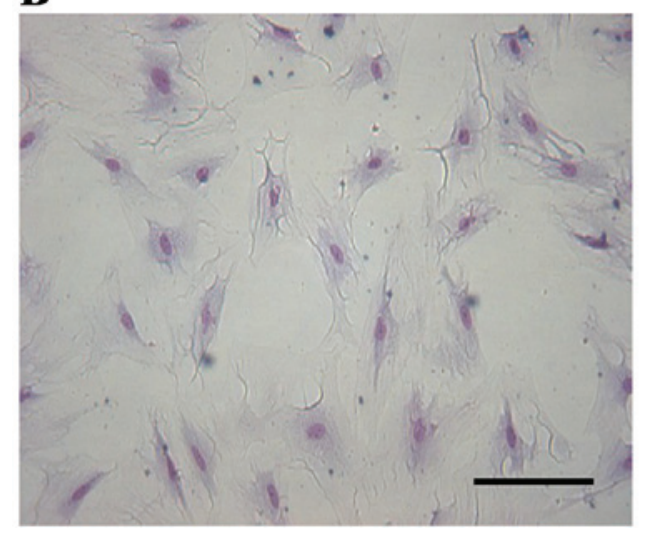

Figure 1. Primary cultured prostatic epithelium in rat. (A) Normal prostatic epithelium at magnification, $\times 100$. (B) Normal prostatic epithelium at x200 magnification. Bar represents $100 \mu \mathrm{m}$.

growth promotion, and there was growth-nhibition with the dose of 1,000 nM, as presented in Fig. 3.

Cell apoptosis. In Annexin V-FITC/PI double staining, the apoptotic cells resisted staining by PI, whilst the necrotic cells did not. All DNA with damaged membranes were dyed fluorescent red by PI, whilst the cells with intact membranes were not dyed. Therefore, these cells did not emit a red fluorescence signal in the early stages of apoptosis, which was exhibited by the normal living cells. These results demonstrated that the apoptosis rate in 0.01-1 nM BPA-treated groups was lower, and the quantity of living cells was higher compared with in the control group, which was consistent with the trends in cell viability, as summarized in Table I. 
$\mathbf{A}$

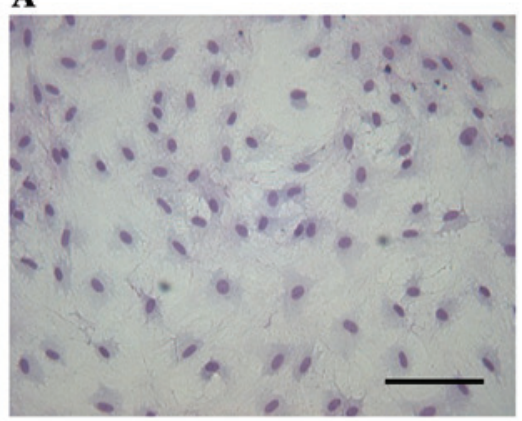

D

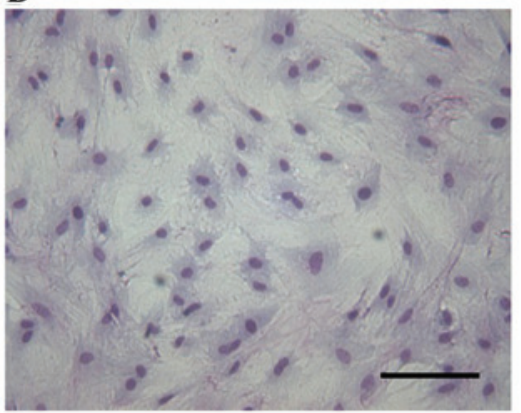

$\mathbf{F}$

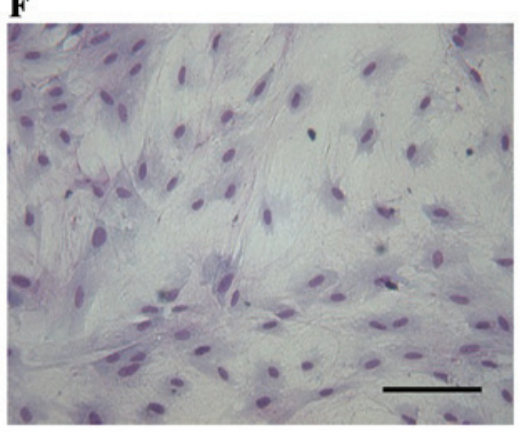

B

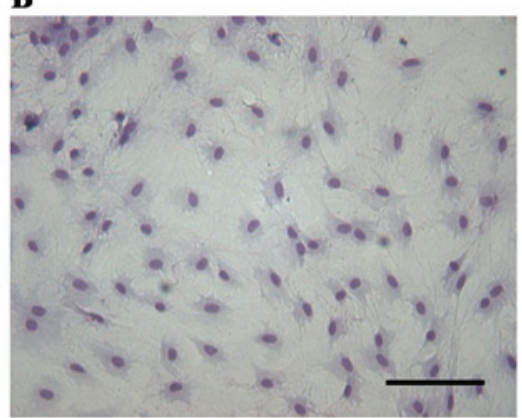

$\mathbf{E}$

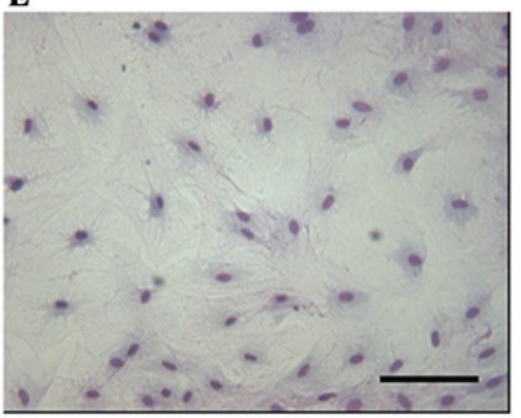

G

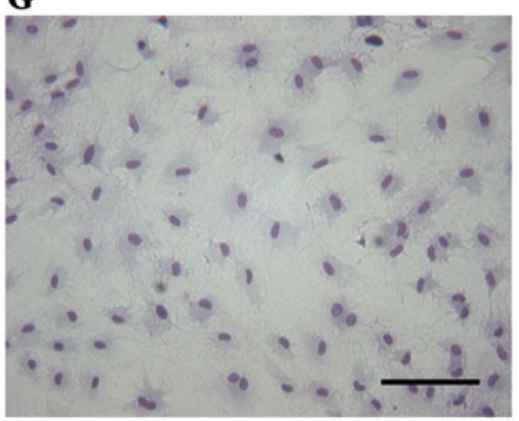

Figure 2. Effect of BPA on primary cultured prostatic epithelial cells. (A) Vehicle control. (B) 0.01 nM BPA. (C) $0.1 \mathrm{nM}$ BPA. (D) $1 \mathrm{nM}$ BPA. (E) $10 \mathrm{nM}$ BPA. (F) $100 \mathrm{nM}$ BPA. (G) $1000 \mathrm{nM}$ BPA. All images at x200 magnification. Bar represents $100 \mu \mathrm{m}$. BPA, Bisphenol A.

Expressions of $A R$ and ER in prostate epithelial cells. Immunocytochemistry analysis revealed that a $0.01-1 \mathrm{nM}$ dose of BPA downregulated the expression of AR $(\mathrm{P}<0.01)$, and this inhibition increased with increasing doses of BPA. Simultaneously, BPA upregulated the expression of ER $\alpha$ and $\operatorname{ER} \beta(P<0.01)$, and the expression of ER $\beta$ increased with increasing dose of BPA, while the expression of ER $\alpha$ decreased slightly, as illustrated in Figs. 4-7.

\section{Discussion}

The exposure to low doses of BPA, an endocrine disruptor, has been demonstrated to induce proliferation of the prostate and aggravation of testosterone-induced BPH in rats, by affecting the prostatic epithelium of the ventral prostate (15). In the present study, prostate epithelial cells were cultured successfully. Prostatic epithelial cells of rats in a primary cultured system were established smoothly under the experimental conditions, which permitted additional investigation into the pathogenesis of $\mathrm{BPH}$ and the mechanism of action of BPA.

Similar to hormones, EDCs are generally reported to demonstrate a bi-phasic dose response as they are stimulating
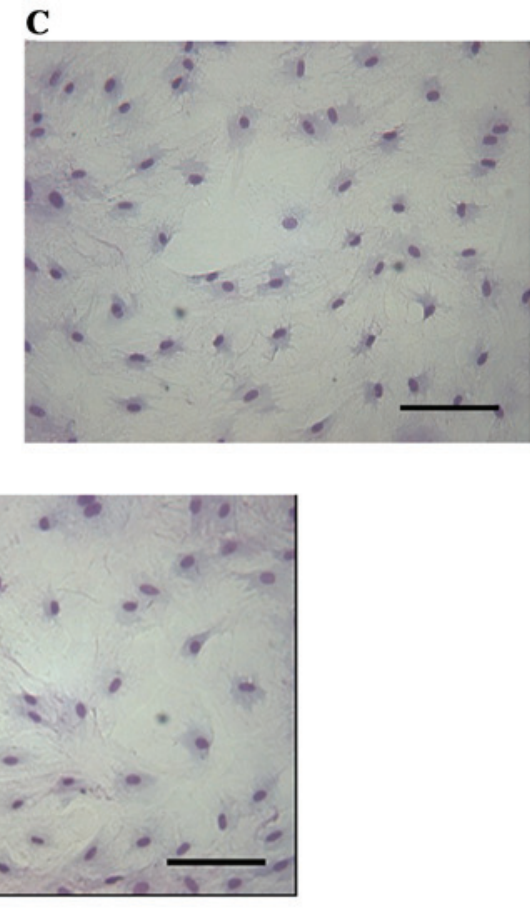
$\mathbf{A}$

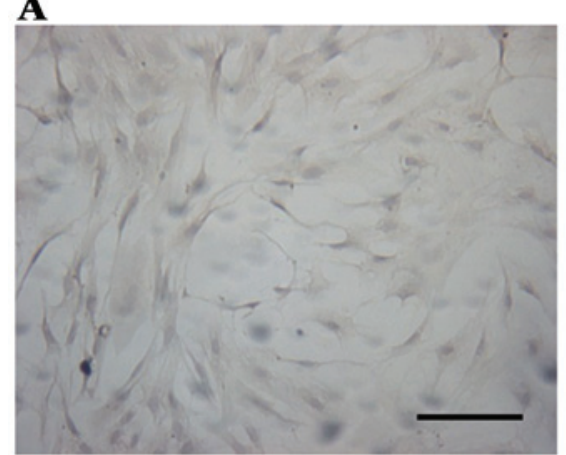

C

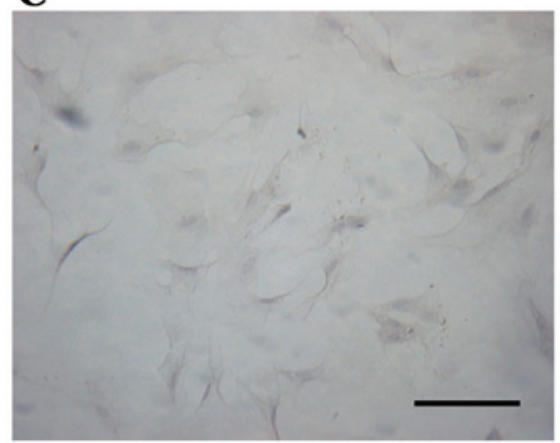

B

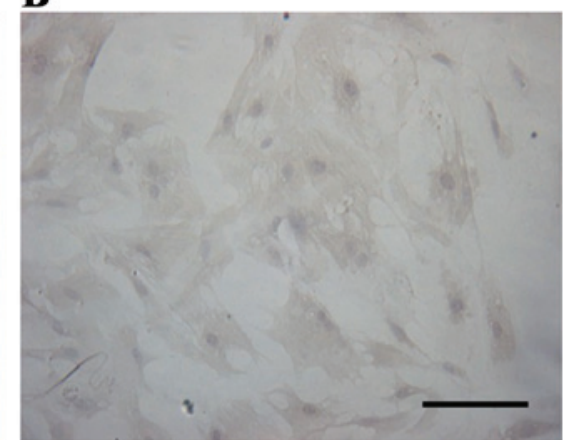

D

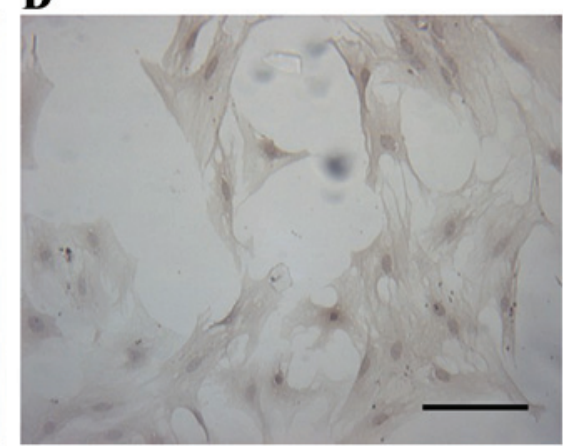

Figure 4. Effect of BPA on androgen receptor expression of primary cultured prostatic epithelial cells. (A) Vehicle control group (B) $0.01 \mathrm{nM}$ BPA. (C) $0.1 \mathrm{nM}$ BPA. (D) $1 \mathrm{nM}$ BPA. All images at x200 magnification. Bar represents $100 \mu \mathrm{m}$. BPA, Bisphenol A.

$\mathbf{A}$

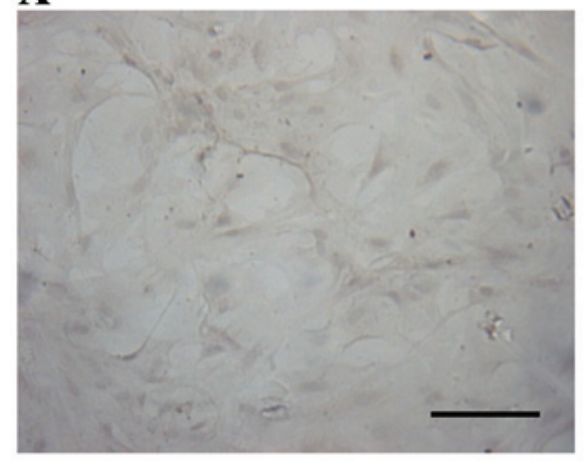

C

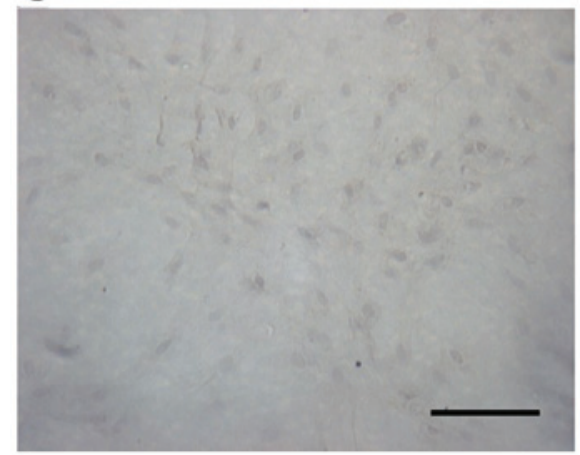

B

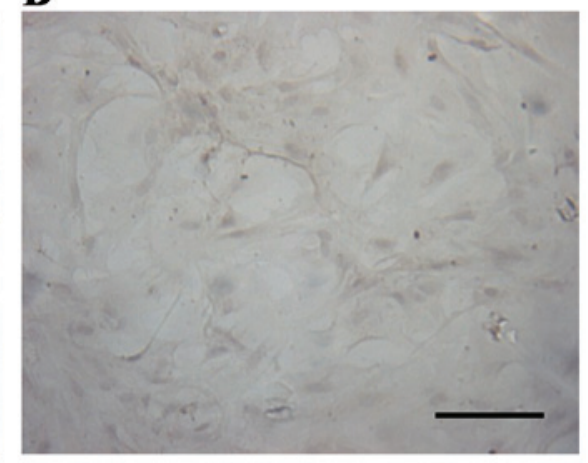

D

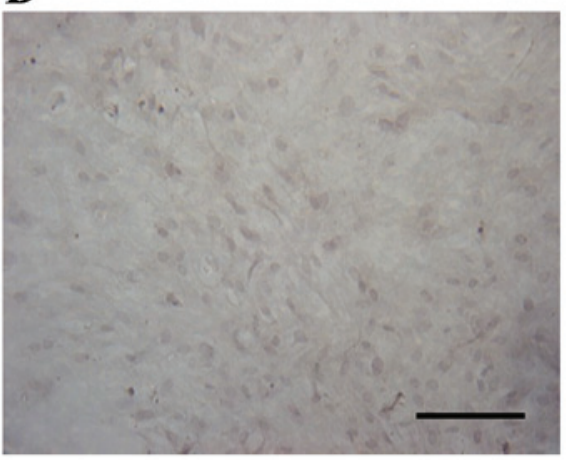

Figure 5. Effect of BPA on estrogen receptor $\alpha$ expression of primary cultured prostatic epithelial cells. (A) Vehicle control group. (B) $0.01 \mathrm{nM}$ BPA. (C) $0.1 \mathrm{nM}$ BPA. (D) $1 \mathrm{nM}$ BPA. All images at x200 magnification. Bar represents $100 \mu \mathrm{m}$. BPA, Bisphenol A.

cell-protecting glutathione. In the present study, cell viability testing by the CCK- 8 method revealed that BPA elicited bi-phasic dose responses, as 0.01-1 nM BPA promoted cell growth, but 10-1,000 nM elicited growth inhibition. The inverse U-shape dose-response curve maybe more marked if the dose interval was diminished. However, the present study focused on the effect of BPA treatment on cell proliferation activity, because it was more applicable. A dose of $1 \mathrm{nM}$ BPA 
$\mathbf{A}$

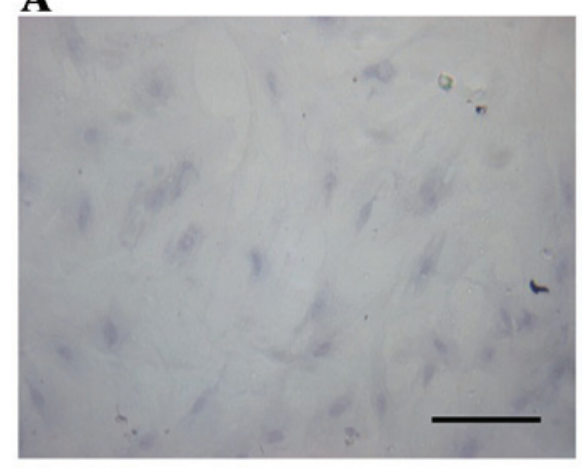

C

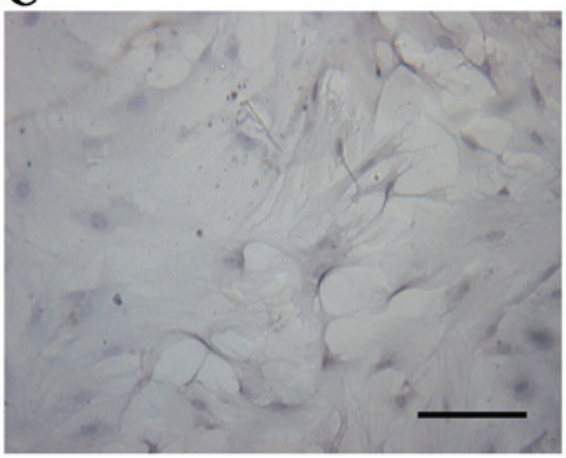

B

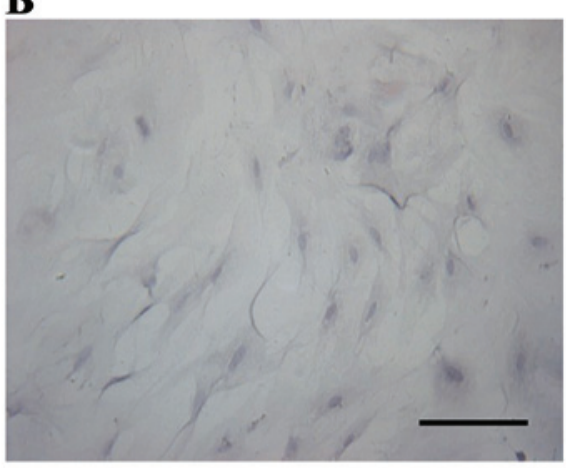

D

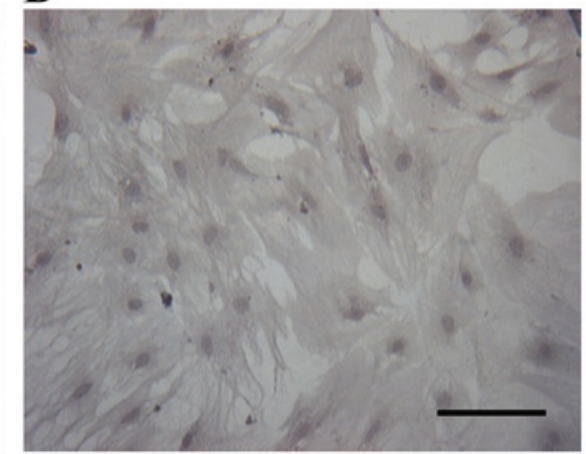

Figure 6. Effect of BPA on estrogen receptor $\beta$ expression of primary cultured prostatic epithelial cells. (A) Vehicle control. (B) $0.01 \mathrm{nM} \mathrm{BPA}$. (C) $0.1 \mathrm{nM}$ BPA (D) $1 \mathrm{nM}$ BPA. All images at x200 magnification. Bar represents $100 \mu \mathrm{m}$. BPA, Bisphenol A.
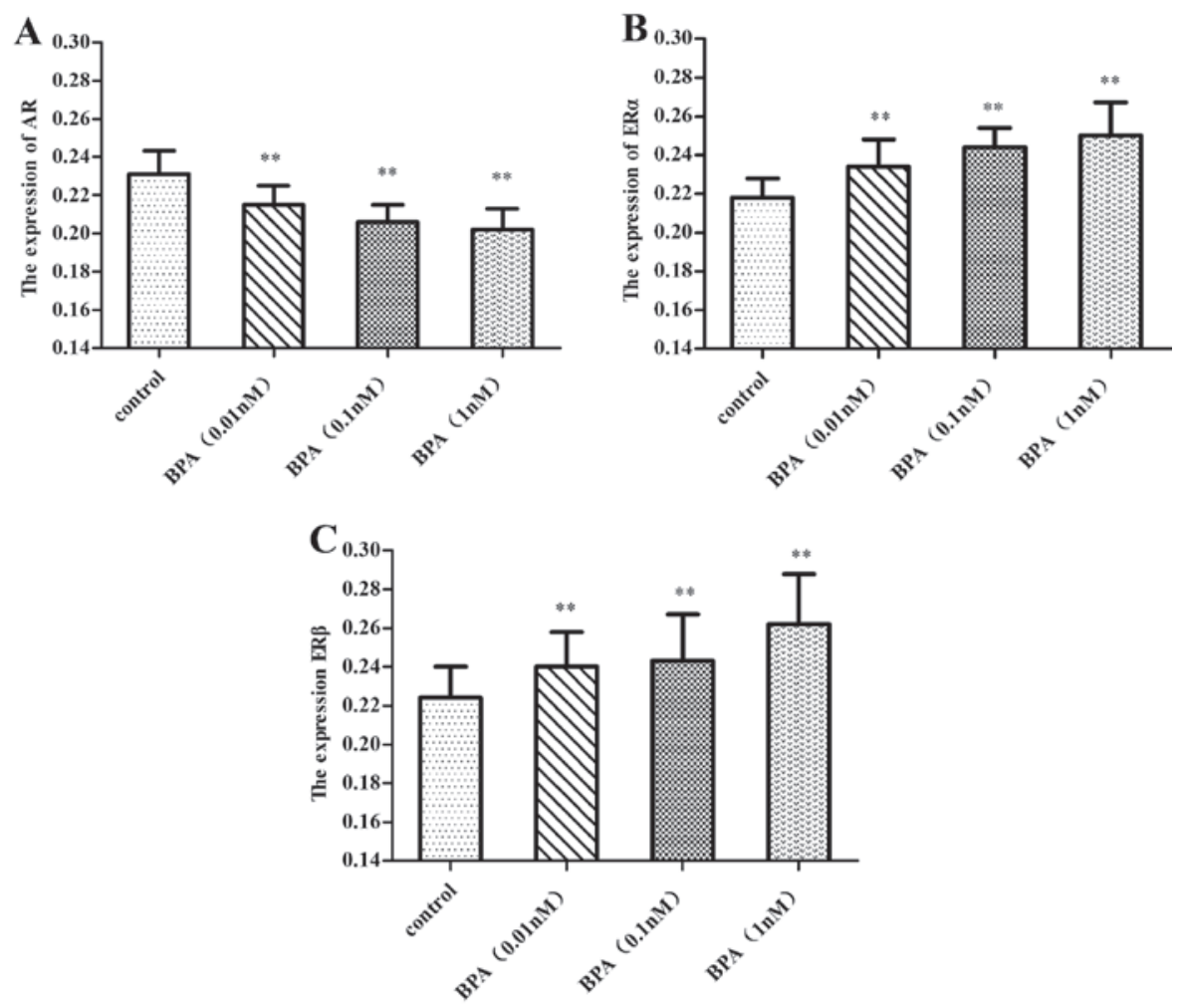

Figure 7. Effect of BPA on the expressions of AR, ER $\alpha$ and $\mathrm{ER} \beta$ of primary cultured prostatic epithelial cells. $\mathrm{n}=120 .{ }^{*} \mathrm{P}<0.05$ vs. control group. ${ }^{* *} \mathrm{P}<0.01$ vs. control group. AR, androgen receptor; ER $\alpha$, estrogen receptor $\alpha$; ER $\beta$, estrogen receptor $\beta 1$; BPA, Bisphenol A.

was equivalent to the BPA detected in serum in environmental exposures (17), which suggests that BPA may promote prostate cell growth directly at an environmental level. This result was consistent with another study that revealed that $1 \mathrm{nM}$ BPA promoted the hyperplasia of testosterone-dependent prostate cancer cells (18). 
Although BPA has been reported to be involved in apoptosis of numerous types of cells, the exposure dose and cell lines may be important factors in how the chemical affects apoptosis. For instance, $100 \mu \mathrm{g} / \mathrm{ml}$ BPA caused comparable apoptosis by increasing cytosolic $\mathrm{Ca}^{2+}$ level, reducing the transmembrane mitochondrial potential, increasing caspase -8 , $-9,-3$ activities and poly (ADP-ribose) Polymerase-1 cleavage in peripheral blood mononuclear cells (19). Zhou et al (20) revealed that in vitro $0.1,1,5$ and $10 \mu \mathrm{g} / \mathrm{ml}$ BPA exposure significantly inhibited germ cell nest breakdown by altering the expression of key ovarian apoptotic genes. BPA appears to inhibit apoptosis at low doses but promotes apoptosis at high doses, which conforms to the effect on cell viability. The present study demonstrated that inhibition of apoptosis was observed in the prostate epithelial cells exposed to 0.01-1 nM BPA, whilst BPA doses of $>1 \mathrm{nM}$ may only exhibit slight cytotoxic effects (21). Therefore, apoptosis may participate in the effects of BPA on the prostate within an appropriate range of exposures.

BPA is considered to exhibit weak estrogenic activity based on the relative binding affinity of the compound for nuclear receptors $\mathrm{ER} \alpha$ and $\mathrm{ER} \beta$, which is $\sim 1,000-10,000$ times less than the affinity of the compound for estradiol (22). ER $\alpha$ exists in the nucleus and is distributed mainly in the prostatic stroma; it may be detected in the epithelium subsequent to exposure to estrogen. ER $\beta$ is a member of the estrogen receptor family and the nuclear receptor superfamily (23). ER $\alpha$ and ER $\beta$ may be involved in the regulation of transcription (24). Generally, ER $\alpha$ promotes the hyperplasia of prostatic epithelial cells, whilst ER $\beta$ possesses anti-proliferative effects (25), which contributes to the maintenance of a dynamic balance between promoting and inhibiting cell growth. BPA combines with ER $(26,27)$, and the responses of ER $\alpha$ and ER $\beta$ to BPA differ as BPA binds to $\mathrm{ER} \alpha$ with a lesser affinity compared with ER $\beta$. In the present study, a combination of BPA and ER led to an increase in the level of ER expression, which correspondingly promoted cell proliferation and inhibition. However, the greatest effect was exhibited in the rates of cell proliferation in the cells treated with lower doses, $0.01-1 \mathrm{nM}$, of BPA. Conversely, with the dose increasing, the inhibition may enhance. In addition to binding to ERs, BPA exposure has been demonstrated to interfere with the thyroid hormone pathway by binding to thyroid hormone receptor (28).

The prostate is an androgen-dependent organ, and AR serves a pivotal role in regulating the function, growth and differentiation of the prostate gland. In the present study, it was revealed that 0.01-1 $\mathrm{nM}$ BPA reduced the expression of AR. BPA exhibits strong antiandrogenic activity, both in vitro and in vivo, with a lower affinity for AR compared with ER $(29,30)$. The AR is a ligand-activated transcription factor and binds to specific elements of the androgen response on target genes to stimulate transcription (31), but this activity is effectively ablated by BPA, leading to the disruption of transcription and androgen-independent prostate cancer cell proliferation (32). Environmental exposures to low doses of BPA activated a mutated AR and promoted testosterone-dependent cell proliferation, and that BPA acts as a ligand for the AR mutant and stimulates cell proliferation at doses of $\leq 1 \mathrm{nM}$ (18). However, there is a debate concerning whether upregulated or downregulated expression of AR is important. The weak estrogenic and antiandrogenic activity of BPA possibly results in an imbalance of estrogen and androgen, leading to an overall increase in the relative levels of estradiol, which is considered a factor leading to the development of BPH (33).

In conclusion, the present study suggests that environmental exposure to BPA directly promoted the proliferation of prostate cells, and that this effect may have been achieved by downregulating the expression of AR and upregulating the expression of ER in cells, inhibiting cell apoptosis. However, the complicated crosstalk amongst different signaling pathways of BPA on the prostate and the possible mechanisms by which BPA activates ER and antagonizes AR functions, alongside the pathways that are involved in apoptosis require future investigation.

\section{Acknowledgements}

The present study was supported by the National Natural Science Foundation of China (grant no. 21007041), the Shanghai Public Service Platform of Research \& Development (grant no. 13DZ2291300) and the Talents Development Foundation of Shanghai Municipality (grant no. 201372).

\section{References}

1. Alonso-Magdalena P, Brössner C, Reiner A, Cheng G, Sugiyama N, Warner M and Gustafsson JA: A role for epithelial-mesenchymal transition in the etiology of benign prostatic hyperplasia. Proc Natl Acad Sci USA 106: 2859-2863, 2009.

2. Tyl RW, Myers CB, Marr MC, Thomas BF, Keimowitz AR, Brine DR, Veselica MM, Fail PA, Chang TY, Seely JC, et al: Three-generation reproductive toxicity study of dietary bisphenol A in CD Sprague-Dawley rats. Toxicol Sci 68: 121-146, 2002.

3. Biedermann S, Tschudin P and Grob K: Transfer of bisphenol A from thermal printer paper to the skin. Anal Bioanal Chem 398: 571-576, 2010.

4. Vandenberg LN, Chahoud I, Heindel JJ, Padmanabhan V, Paumgartten FJ and Schoenfelder G: Urinary, circulating, and tissue biomonitoring studies indicate widespread exposure to bisphenol A. Environ Health Perspect 118: 1055-1070, 2010.

5. Vandenberg LN, Colborn T, Hayes TB, Heindel JJ, Jacobs DR Jr, Lee DH, Shioda T, Soto AM, vom Saal FS, Welshons WV, et al: Hormones and endocrine-disrupting chemicals: Low-dose effects and nonmonotonic dose responses. Endocr Rev 33: 378-455, 2012.

6. Ramos JG, Varayoud J, Sonnenschein C, Soto AM, Muñoz-de-Toro M and Luque EH: Prenatal exposure to low doses of bisphenol A alters the periductal stroma and glandular cell function in the rat ventral prostate. Biol Reprod 65: 1271-1277, 2001.

7. Derouiche S, Warnier M, MariotP, Gosset P, Mauroy B, Bonnal JL, Slomianny C, Delcourt P, Prevarskaya N and Roudbaraki M: Bisphenol A stimulates human prostate cancer cell migration via remodelling of calcium signalling. Springerplus 2: 54, 2013.

8. Takahashi $\mathrm{O}$ and Oishi S: Testicular toxicity of dietary 2,2-bis(4-hydroxyphenyl)propane (bisphenol A) in F344 rats. Arch Toxicol 75: 42-51, 2001

9. Herath CB, Jin W, Watanabe G, Arai K, Suzuki AK and Taya K: Adverse effects of environmental toxicants, octylphenol and bisphenol $\mathrm{A}$, on male reproductive functions in pubertal rats. Endocrine 25: 163-172, 2004.

10. Ogura Y, Ishii K, Kanda H, Kanai M, Arima K, Wang YZ and Sugimura Y: Bisphenol A induces permanent squamous change in mouse prostatic epithelium. Differentiation 75: 745-756, 2007.

11. Ho SM, Tang WY, Belmonte de Frausto J and Prins GS: Developmental exposure to estradiol and bisphenol A increases susceptibility to prostate carcinogenesis and epigenetically regulates phosphodiesterase type 4 variant 4 . Cancer Res 66: 5624-5632, 2006. 
12. Wu J, Huang D, Su X, Yan H and Sun ZY: Oral administration of low-dose bisphenol A promotes proliferation of ventral prostate and upregulates prostaglandin D2 synthase expression in adult rats. Toxicol Ind Health pii: Jun 18, 2015 (Epub ahead of print).

13. Wang JF, Zhou Y, LIU JH, et al: Guide for the Care and Use of Laboratory Animals. Shanghai Scientific \& Technical Publishers (SSTP), Shanghai, China, 2012.

14. Mckeehan WL, Adams PS and Rosser MP: Direct mitogenic effects of insulin, epidermal growth factor, glucocorticoid, cholera toxin, unknown pituitary factors and possibly prolactin, but not androgen, on normal rat prostate epithelial cells in serum-free, primary cell culture. Cancer Res 44: 1998-2010, 1984

15. Wu JH, Jiang XR, Liu GM, Liu XY, He GL and Sun ZY: Oral exposure to low-dose bisphenol A aggravates testosterone-induced benign hyperplasia prostate in rats. Toxicol Ind Health 27: 810-819, 2011.

16. Gualtieri AF, Iwachow MA, Venara M, Rey RA and Schteingart HF: Bisphenol A effect onglutathione synthesis and recycling in testicular Sertoli cells. J Endocrinol 5: e102-e109, 2011.

17. Wetherill YB, Hess-Wilson JK, Comstock CE, Shah SA, Buncher CR, Sallans L, Limbach PA, Schwemberger S, Babcock GF and Knudsen KE: Bisphenol A facilitates bypass of androgen ablation therapy in prostate cancer. Mol Cancer Ther 5 3181-3190, 2006

18. Hess-Wilson JK, Webb SL, Daly HK, Leung YK, Boldison J, Comstock CE, Sartor MA, Ho SM and Knudsen KE: Unique bisphenol A tanscriptom in prostate cancer: Novel effects on ERbeta expression that correspond to androgen receptor mutation status. Environ Health Perspect 115: 1646-1653, 2007.

19. Mokra K, Kocia M and Michałowicz J: Bisphenol A and its analogs exhibit different apoptotic potential in peripheral blood mononuclear cells (in vitro study). Food Chem Toxicol 84: 79-88, 2015.

20. Zhou C, Wang W, Peretz J and Flaws JA: Bisphenol A exposure inhibits germ cell nest breakdown by reducing apoptosis in cultured neonatal mouse ovaries. Reprod Toxicol 57: 87-99, 2015

21. Iida H, Maehara K, Doiguchi M, Mōri T and Yamada F: Bisphenol A-induced apoptosis of cultured rat Sertoli cells. Reprod Toxicol 17: 457-464, 2003.

22. Kuiper GG, Lemmen JG, Carlsson B, Corton JC, Safe SH, van der Saag PT, van der Burg B and Gustafsson JK: Interaction of estrogenic chemicals and phytoestrogens with estrogen receptor $\beta$. Endocrinology 139: 4252-4263, 1998.
23. Omoto Y, Imamov O, Warner M and Gustafsson JA: Estrogen receptor alpha and imprinting of the neonatal mouse ventral prostate by estrogen. Proc Natl Acad Sci USA 102: 1484-1489, 2005.

24. Adams JY, Leav I, Lau KM, Ho SM and Pfluege SM: Expression of estrogen receptor beta in the fetal, neonatal, and prepubertal human prostate. Prostate 52: 69-81, 2002.

25. Taylor JA, Richter CA, Ruhlen RL and vom Saal FS: Estrogenic environmental chemicals and drugs: Mechanisms for effects on the developing male urogenital system. J Steroid Biochem Mol Biol 127: 83-95, 2011.

26. Vandenberg LN, Maffini MV, Sonnenschein C, Rubin BS and Soto AM: Bisphenol A and the great divide: A review of controversies in the field of endocrine disruption. Endocr Rev 30: 75-95, 2009.

27. Weng YI, Hsu PY, Liyanarachchi S, Liu J, Deatherage DE, Huang YW, Zuo T, Rodriguez B, Lin $\mathrm{CH}$, Cheng AL and Huang TH: Epigenetic influences of low-dose bisphenol A in primary human breast epithelial cells. Toxicol Appl Pharmacol 248: 111-121, 2010.

28. Rubin BS: Bisphenol A: An endocrine disruptor with widespread exposure and multiple effects. J Steroid Biochem Mol Biol 127: 27-34, 2011.

29. Luccio-Camelo DC and Prins GS: Disruption of androgen receptor signaling in males by environmental chemicals. J Steroid Biochem Mol Biol 127: 74-82, 2011.

30. Bonefeld-Jørgensen EC, Long M, Hofmeister MV and Vinggaard AM: Endocrine-disrupting potential of bisphenol A. bisphenol A dimethacrylate, 4-nnonylphenol, and 4-n-octylphenol in vitro: New data and a brief review. Environ Health Perspect 115 (Suppl 1): S69-S76, 2007.

31. Wetherill YB, Fisher NL, Staubach A, Danielsen M, de Vere White RW and Knudsen KE: Xenoestrogen action in prostate cancer: Pleiotropic effects dependent on androgen receptor status. Cancer Res 65: 54-65, 2005.

32. Wetherill YB, Petre CE, Monk KR, Puga A and Knudsen KE: The xenoestrogen bisphenol A induces inappropriate androgen receptor activation and mitogenesis in prostatic adenocarcinoma cells. Mol Cancer Ther 1: 515-524, 2002.

33. Lee $\mathrm{CH}$, Akin-Olugbade $\mathrm{O}$ and Kirschenbaum A: Overview of prostate anatomy, histology, and pathology. Endocrinol Metab Clin North Am 40: 565-575, viii-xi, 2011. 